\title{
Four Awards of the Li Fang-Kuei Society for Chinese Linguistics 四種獎項及申請辦法
}

Four Awards are set up in memory of the contribution to Chinese Linguistics by the Master Linguist, the late Professor Li Fang-Kuei:
1. LFK Book Award
2. LFK Dissertation Award
3. $\quad$ LFK Field Work Award
4. LFK Conference Travel Grant Award

For details of these awards and their application procedure, please see our web site www.lfksociety.org. According to Internal Revenue Service regulations, applicants for these awards cannot serve on the Board of Directors or be Officers of, or major donors to, the Li Fang-Kuei Society of Chinese Linguistics, nor can the applicants be closely related to them. ${ }^{1}$

紀念李方桂先生中國語言學研究學會為紀念語言學大師李方桂先生對中國語言學 的貢獻, 設立以下四種獎項：

1. 李方桂語言學論著獎
2. 李方桂學會博士論文獎
3. 李方桂田野調查獎
4. 李方桂研究生學術會議旅費資助獎金

四種獎項的內容及申請辦法, 詳見本學會網站 www.lfksociety.org。

按美國聯邦稅務局條例, 申請人不得是紀念李方桂先生中國語言學研究學會的執行委員、 董事、主要捐款者、或與他們有密切關係者。2

\footnotetext{
1 "Major donors" refers to donors of over Us $\$ 5,000$ or of an accumulated amount over $2 \%$ of the endowment of the Li FangKuei Society.

2 “主要捐款者” 指捐款總額超過 5,000 美元或者迄今捐款超過本會基金總數百分之二的人。 